\title{
牧 \\ LEGADOS DAS PARALIMPÍADAS ESCOLARES PARA O ESPORTE PARALÍMPICO NO BRASIL
}

\section{LEGACIES OF SCHOOL PARALYMPICS FOR PARALYMPIC SPORT IN BRAZIL \\ LEGADOS DE LAS PARALIMPIADAS ESCOLARES PARA EL DEPORTE PARALÍMPICO EN BRASIL}

Giandra Anceski Bataglion ${ }^{1}$ Janice Zarpellon Mazo ${ }^{2}$

Resumo: O objetivo desta pesquisa foi verificar como se constituiu a participação do Rio Grande do Sul nas Paralimpíadas Escolares no período de 2010 a 2018 e suas ressonâncias para o esporte paralímpico escolar no estado. Para tanto, foram coletadas informações em documentos oficiais e em mídias digitais que veicularam notícias sobre o tema. A análise documental das informações coletadas evidenciou que em 2010 o estado enfrentou dificuldades para participar da competição, tendo em vista a carência de ações no âmbito do esporte voltadas aos estudantes com deficiência. Contudo, a partir do ano seguinte, em 2011, iniciativas governamentais foram implementadas. As ações parecem ter contribuído na promoção de tais práticas nas escolas, associações e clubes esportivos do estado, produzindo um gradual incremento do desempenho nas Paralimpíadas Escolares, com destaque para a edição de 2018.

Palavras-chave: Paralimpíadas Escolares. Esporte Paralímpico Escolar. Estudantes com Deficiência. Estudo Sociocultural. História do Esporte.

Abstract: The objective of this research was to verify how Rio Grande do Sul's participation in the School Paralympics was constituted in the period from 2010 to 2018, and its resonances for the paralympic sport in the state. For that, information was collected in official documents and in digital media, which provided news about the theme. The documentary analysis of the

\footnotetext{
${ }^{1}$ Doutoranda do Programa de Pós-Graduação em Ciências do Movimento Humano, da Universidade Federal do Rio Grande do Sul (UFRGS). Integrante do Centro de Memória do Esporte (CEME), do Observatório do Esporte Paralímpico e do Núcleo de Estudos em História e Memória do Esporte e da Educação Física (NEHME), da UFRGS. Pesquisa sobre os temas: Esporte para Pessoas com Deficiência, Esporte Paralímpico Escolar e Esportes Surdos. (giandraanceski@gmail.com)

2 Professora Doutora da Escola de Educação Física, Fisioterapia e Dança e do Programa de PósGraduação em Ciências do Movimento Humano, da Universidade Federal do Rio Grande do Sul (UFRGS). Coordenadora do Centro de Memória do Esporte (CEME), do Observatório do Esporte Paralímpico e do Núcleo de Estudos em História e Memória do Esporte e da Educação Física (NEHME), da UFRGS. Pesquisa sobre os temas: História do Esporte e da Educação Física, Esporte para Pessoas com Deficiência e Esportes Surdos. (janice.mazo@ufrgs.br)
} 
information collected showed that in 2010 , the state faced difficulties to participate in the competition, due to the lack of actions in the field of sport, aimed at students with disabilities. However, from the following year, in 2011, government initiatives were implemented. The actions seem to have contributed to the promotion of such practices in schools, associations and sports clubs of the state, reflecting a gradual increase in performance in the Paralympics School, with emphasis on the 2018 edition.

Keywords: School Paralympics. School Paralympic Sport. Students with Disabilities. Sociocultural Study. History of Sport.

Resumen: El objetivo de esta investigación fue verificar cómo se constituyó la participación de Rio Grande do Sul en las Paralimpíadas Escolares, en el período de 2010 a 2018, y sus resonancias para el deporte paralímpico escolar en el estado. Para ello, se recogieron informaciones en documentos oficiales y en medios digitales, que transmitieron noticias sobre el tema. El análisis documental de las informaciones recolectadas evidenció que en 2010, el estado enfrentó dificultades para participar en la competición, teniendo en cuenta la carencia de acciones en el ámbito del deporte, dirigidas a los estudiantes con discapacidad. Sin embargo, a partir del año siguiente, en 2011, se implementaron iniciativas gubernamentales. Las acciones parecen haber contribuido en la promoción de tales prácticas en las escuelas, asociaciones y clubes deportivos del estado, reflejando en un gradual incremento del desempeño en las Paralimpíadas Escolares, con destaque para la edición de 2018.

Palabras clave: Paralimpíadas Escolares. Deporte Paralímpico Escolar. Estudiantes con discapacidad. Estudio Sociocultural. Historia del Deporte.

\section{Introdução}

Paralimpíadas Escolares ${ }^{3}$ é uma competição esportiva composta por distintas modalidades paralímpicas ${ }^{4}$, na qual participam estudantes com as deficiências ${ }^{5}$ física, visual e

\footnotetext{
${ }^{3}$ Para as edições do evento realizadas até o ano de 2011, utilizamos o termo Paraolimpíadas Escolares, em conformidade com o termo originalmente utilizado nas respectivas edições. A partir do ano de 2012, passou-se a utilizar o termo Paralimpíadas Escolares, em consonância com o termo Paralímpico adotado pelo CPB no ano de 2011, atendendo à padronização proposta pelo International Paralympic Committee (IPC), em língua portuguesa denominado Comitê Paralímpico Internacional. Desta forma, das edições do ano de 2012 a 2018, utilizamos o termo oficial e atual do evento, qual seja: Paralimpíadas Escolares.

${ }^{4}$ As modalidades paralímpicas disputadas nas Paralimpíadas Escolares até o ano de 2018 são: atletismo, basquete em cadeira de rodas, bocha, futebol de cinco, futebol de sete, goalball, judô, natação, tênis de mesa, tênis em cadeira de rodas e vôlei sentado (PARALIMPÍADAS..., 2018). As modalidades disputadas nas Paralimpíadas Escolares integram o programa dos Jogos Paralímpicos.

${ }^{5}$ Pessoas com deficiência são aquelas que têm impedimentos de longo prazo de natureza física, mental, 
intelectual. O evento é uma ação do Comitê Paralímpico Brasileiro (CPB) que congrega estados brasileiros (SILVA, 2017), os quais são responsáveis pela organização de suas delegações a cada edição da competição (BATAGLION; MAZO, 2019). É permitida a participação de estudantes dos sexos masculino e feminino, na faixa etária dos 12 aos 18 anos, os quais devem estar regularmente matriculados e frequentando instituição de ensino fundamental, médio ou especial, pública ou privada, reconhecida pelo Ministério da Educação (PARALIMPÍADAS..., 2018).

Esta competição é promovida pelo CPB desde o ano 2006, tendo o Projeto Paraolímpicos do Futuro como seu precursor (CARDOSO, 2016; GORLA; CALEGARI, 2017; HAIACHI et al., 2018). Todavia, as duas primeiras edições foram realizadas com as seguintes denominações: I Campeonato Paraolímpico Escolar Brasileiro de Atletismo e Natação (2006) e II Campeonato Paraolímpico Escolar Brasileiro (2007). No ano de 2008 o evento não foi realizado e, a partir do ano seguinte, em 2009, passou a realizar-se anualmente com a denominação "Paraolimpíadas Escolares". Atualmente, podemos dizer que o evento conquistou ampla abrangência, mobilizando todas as unidades federativas do país para a vinculação de suas delegações às Paralimpíadas Escolares (SCHERER; GOULART; SERON, 2018).

Os estudos de Silva (2017) e Furtado (2017) enfocaram as Paralimpíadas Escolares como um evento circunscrito, prioritariamente, ao alto rendimento esportivo, dadas as características de seleção e as intenções direcionadas à detecção de futuros talentos paralímpicos. Com base nas afirmações das autoras citadas, é possível considerar as Paralimpíadas Escolares como uma das portas de entrada para o esporte paralímpico de alto rendimento. De tal modo, nas unidades federativas do país, o evento é formatado visando à seleção daqueles que têm o melhor desempenho esportivo para disputar a competição nacional.

Por sua vez, Resende (2018) ressaltou a relevância da participação dos estudantes com deficiência nas Paralimpíadas Escolares, apontando influências em seus planos futuros, no que se refere à prática de modalidades paralímpicas, bem como no sentimento de pertencimento social, a partir do reconhecimento de suas potencialidades em seus contextos. Assim, a autora destaca que as oportunidades no esporte paralímpico escolar suscita ressignificações nas vidas das crianças e jovens com deficiência. Neste sentido, afora as representações atreladas ao alto rendimento esportivo, a competição trabalha com objetivos na esfera da inclusão social ${ }^{6}$, tendo isto como uma perspectiva de longo prazo (SENATORE, 2006), a ser traçada por intermédio de

intelectual ou sensorial, os quais, em interação com diversas barreiras, podem obstruir sua participação plena e efetiva na sociedade em igualdade de condições com as demais pessoas (BRASIL, 2009, p. 27).

${ }^{6}$ Em nosso estudo, a inclusão social deve ser pensada para além do mero compartilhamento de espaços e tempos. Logo, compreende-se que os estados devem assegurar que as crianças com deficiência possam, em condições iguais às de seus pares sem deficiência, participar de práticas esportivas, inclusive no contexto escolar (BRASIL, 2009). Ademais, devem promover e oportunizar o engajamento em modalidades específicas aos tipos de deficiência, "incentivando a provisão de instrução, treinamento e recursos adequados, em igualdade de oportunidades com as demais pessoas", de acordo com a Convenção 
práticas estabelecidas em nível estadual e municipal, extrapolando as dimensões do evento nacional (BRASIL, 2011). Isso significa, nos dizeres de Haiachi et al (2018), que a inclusão precisa circunscrever um desafio/movimento constante no ambiente esportivo, pois "não se trata apenas de aceitar um diferente em nosso meio" (p. 164), mas, sim, de construir as condições para a sua efetiva participação esportiva em qualquer espaço.

Em vista da representatividade alcançada ao longo de suas edições, as Paralimpíadas Escolares são referidas como a maior competição esportiva do mundo para estudantes com deficiência (CARDOSO, 2016; SILVA, 2017; GOULART, 2017; HIPÓLITO; WINCKLER, 2018), todavia, acreditamos na relevância de se investigar as peculiaridades que circunscrevem as composições históricas desse evento em cenários regionais. Isto porque ações no âmbito estadual e municipal acerca do esporte paralímpico escolar ${ }^{7}$ integram as conformações da participação de cada estado brasileiro nas Paralimpíadas Escolares. Nesta esfera há distintos cenários. Algumas ocasiões apresentam ações esportivas para estudantes com deficiência, as quais antecedem e prosseguem na mera participação no evento nacional, isto é, com objetivos de longo prazo. Em outras situações, as iniciativas são realizadas de modo emergencial e passageiro, possibilitando apenas a formação de delegações para o evento sem, no entanto, promover e oferecer as condições necessárias para a inclusão permanente desses estudantes na prática de modalidades paralímpicas (ANDRADE et al., 2014; REIS; SOUSA, 2015; NETO; ABRAHÃO; MOURA, 2017; MACHADO et al., 2017).

O estudo de Cardoso (2017) traz o exemplo do estado de Roraima, que, até a edição de 2016, teve uma única participação nas Paralimpíadas Escolares, no ano de 2013. O autor atribuiu isso à ausência de oportunidades para o desenvolvimento do esporte paralímpico escolar e de alto rendimento no referido estado e sugeriu a implementação de ações no campo a partir de políticas públicas estaduais. Por sua vez, no estado do Rio Grande do Sul, são referidas contribuições de ações governamentais e não governamentais nas composições das Paralimpíadas Escolares em nível regional (GUIMARÃES et al., 2014; ROMERO, 2017; MALANOVICZ; MARTINS; MALANOVICZ, 2017). Cabe mencionar que a maior parte dos participantes das Paralimpíadas Escolares é oriunda de instituições de ensino regular públicas, seguidos por representantes de escolas privadas e, em menor percentual, de instituições de ensino especiais (REIS; SILVA; MEZZADRI, 2017), sobrelevando a relevância do desenvolvimento de políticas públicas nessa área.

Nessa direção, há de se considerar os elementos socioculturais e político-econômicos que circunscrevem as composições históricas das Paralimpíadas Escolares em cada contexto do

dos Direitos das Pessoas com Deficiência (2009, p. 60).

${ }^{7}$ Neste estudo, compreendemos o esporte paralímpico escolar como todas as ações em que crianças e jovens com deficiência, matriculados em instituições de ensino fundamental ou médio, participam, regularmente, da prática esportiva em modalidades paralímpicas, seja em contexto escolar ou em associações, clubes, projetos sociais, etc. 
país. Nesta perspectiva, o recorte espacial de nosso estudo se limita ao estado do Rio Grande do Sul, o qual teve sua primeira participação nas Paralimpíadas Escolares no ano de 2010, não participando das três primeiras edições da competição. Há vestígios de que, desde as décadas de 1960 e 1970, aproximadamente, alguns esportes eram praticados por pessoas com deficiência no Rio Grande do Sul (BEGOSSI; MAZO, 2016), por intermédio de instituições como o Instituto Santa Luzia e a Associação de Cegos do Rio Grande do Sul (ACERGS), ambas referência em atendimento à população com deficiência visual. Nos espaços da primeira entidade citada, em especial, sabe-se que estudantes com deficiência contavam com a prática de esportes como o futebol e o atletismo. Não obstante, a instituição recepcionou, ainda na década de 1970, a primeira competição esportiva para pessoas com deficiência visual do país.

Pondera-se, também, sobre as associações de pais e amigos dos excepcionais (APAES) do Rio Grande do Sul, que atuam nas áreas da educação física, desporto e lazer, especialmente, com atividades direcionadas à população com deficiências intelectuais e múltiplas, através do assessoramento da Federação das APAES do Estado do Rio Grande do Sul (FEAPAES-RS), fundada em 1993 (A FEDERAÇÃO..., 2019). Entretanto, é possível que práticas esportivas tenham sido desenvolvidas nesses espaços em décadas anteriores.

Nas décadas seguintes, principalmente a partir do ano de 2000, entidades foram fundadas, assumindo, também, a tarefa de promover o esporte para as pessoas com deficiência no estado (MAZO et al., 2018). Dentre elas, podemos citar alguns exemplos: RS Paradesporto; Associação de Servidores da Área de Segurança, Portadores de Deficiências, do Rio Grande do Sul (ASASEPODE); Associação de Pais, Amigos e Pessoas com Deficiência, de Funcionários do Banco do Brasil e da Comunidade (APABB); Federação de Paradesporto do Estado do Rio Grande do Sul (FEPARGS), Associação Gaúcha de Futebol para Cegos (AGAFUC).

Embora os indícios apontem que, em um primeiro momento as práticas esportivas para as pessoas com deficiência tiveram representações marcadas pela participação e, inclusive, pela competição entre estudantes de instituição educacional para cegos do Rio Grande do Sul, estudos realizados sobre o assunto permitem considerar que as crianças e jovens com deficiência do estado não foram imediatamente inseridas nas iniciativas esportivas das demais entidades mencionadas (BEGOSSI; MAZO, 2016; MAZO et al., 2018). Igualmente, até o ano de 2011, o estado não contemplava o esporte paralímpico escolar em suas políticas públicas de esporte (TONDIN; VIDAL; FEIX, 2014). Desta feita, especialmente no âmbito da prática de modalidades paralímpicas de forma estruturada e contínua, ponderamos que as crianças e jovens estudantes com deficiência sul-rio-grandenses conquistaram visibilidade e oportunidades em períodos bastante recentes. Assim, levamos em consideração que o tema do esporte paralímpico escolar faz parte de uma memória esportiva do tempo presente no estado.

Conforme procuramos retratar nos parágrafos supracitados, talvez em decorrência das características de composição do campo, inicialmente o estado do Rio Grande do Sul enfrentou 
dificuldades para participar das Paralimpíadas Escolares, o que estimulou a estruturação de ações governamentais, visando ao desenvolvimento do esporte paralímpico escolar nos municípios do estado (BATAGLION; GUIMARÃES; MAZO, 2018). Partindo da identificação da carência de ações ligadas ao esporte para estudantes com deficiência, agentes de órgãos governamentais responsáveis por essa esfera ampliaram suas redes, buscando ligação com distintas localidades do Rio Grande do Sul (SEHBE, 2014; GUIMARÃES, 2014), de modo a fortalecer as tramas dessa composição. Após a primeira participação do Rio Grande do Sul nas Paralimpíadas Escolares, em 2010, três ações governamentais foram planejadas no estado, com foco no fomento ao esporte paralímpico escolar, as quais passaram a ser desenvolvidas a partir de 2012, sendo elas: a) Clínica de Esportes Paralímpicos - ação de capacitação de professores de educação física; b) Festival Paralímpico do Rio Grande do Sul - evento pautado em oficinas de esportes paralímpicos para a participação de crianças e jovens com deficiência; e c) Campeonato Paradesportivo Estudantil do Rio Grande do Sul (PARACERGS) - competição seletiva às Paralimpíadas Escolares. Paralelamente a essas ações, escolas, associações e clubes esportivos foram incentivados a promover a inserção de estudantes com deficiência na prática de modalidades paralímpicas (BATAGLION; GUIMARÃES; MAZO, 2018). Diante de tais considerações, o objetivo desta pesquisa, a qual faz parte de uma tese de doutorado, é verificar como se constituiu a participação do Rio Grande do Sul nas Paralimpíadas Escolares, no período de 2010 a 2018, e suas ressonâncias para o esporte paralímpico escolar no estado.

O tema do esporte paralímpico escolar faz parte de uma memória esportiva do tempo presente no Rio Grande do Sul. Talvez, por isso, os registros em acervos institucionais são um tanto escassos, até mesmo por motivos políticos que envolvem mudanças de governo e, muitas vezes, o apagamento de ações, por meio de diversas estratégias das administrações. Um dos intuitos deste estudo é, além de asseverar a importância de registro, preservação e divulgação da memória sobre o esporte paralímpico nos diferentes âmbitos, alertar para os discursos circulantes que silenciam sobre a prática esportiva para crianças e adolescentes com deficiência na escola. Há indícios de como fatores políticos e, de certa forma, econômicos, influenciaram as composições das ações dirigidas ao esporte paralímpico escolar e, inclusive, as representações que foram construídas acerca do fenômeno no contexto sociocultural do estado.

\section{Procedimentos metodológicos}

Para o desenvolvimento deste estudo sociocultural sobre o esporte, foram coletadas informações nos boletins oficiais das Paralimpíadas Escolares, do período de 2010 a 2018, acessados por meio do site oficial do CPB. Além disso, utilizamos documentos oficiais da Secretaria Estadual do Esporte e Lazer (SEL) do Rio Grande do Sul referentes ao desenvolvimento de ações no campo do esporte paralímpico escolar. Por fim, reunimos um 
conjunto de notícias veiculadas no site do Governo do estado, acerca da participação dos estudantes sul-rio-grandenses, nas edições das Paralimpíadas Escolares. Para além de tais materiais, realizamos uma revisão bibliográfica sobre o objeto de estudo investigado, a qual indicou um número reduzido de pesquisas sobre o tema.

A técnica de análise documental foi aplicada para a interpretação dos materiais coletados. Desse modo, as informações passaram pelas etapas de fichamento, incluindo a disposição em categorias; análise, contextualizando e decifrando as informações de acordo com o contexto e o período de sua elaboração; e cruzamento dos materiais, confrontando os indícios oriundos de cada um deles (BARROS, 2012). A análise resultou na elaboração do capítulo apresentado abaixo, o qual foi discutido à luz da revisão bibliográfica realizada sobre o objeto de estudo em questão.

\section{Paralimpíadas Escolares: representações e legados no Rio Grande do Sul}

A participação do Rio Grande do Sul nas Paralimpíadas Escolares pode ser caracterizada em três fases, conforme nomeamos: 1) Fase Elementar; 2) Fase da Conformação; 3) Fase de Incremento. A primeira, demarcada no ano de 2010, caracterizou-se pelas dificuldades relacionadas à falta de recursos financeiros para enviar a pequena delegação, composta por quatro estudantes e seis membros da equipe técnica, para a competição realizada em São Paulo/SP. Na ocasião, os representantes disputaram provas na modalidade do atletismo paralímpico e obtiveram a $22^{\mathrm{a}}$ colocação final na competição. Tais indícios revelaram a carência de iniciativas do esporte para estudantes com deficiência no estado naquela época. De tal modo, a primeira participação do Rio Grande do Sul nas Paralimpíadas Escolares sucedeu de forma tímida, tendo em vista as dificuldades enfrentadas para a viabilização da organização e o deslocamento da pequena delegação sul-rio-grandense ao evento. Essa conjuntura, após o retorno da delegação ao estado, suscitou representações que enfatizavam os "feitos dos atletas e técnicas gaúchos" (PARAOLIMPÍADAS..., 2011). Afora valorizar o empenho e a garra da delegação, tais representações estimularam, no ano seguinte, em 2011, o apoio da Fundação de Esporte e Lazer do Estado do Rio Grande do Sul (FUNDERGS) e da Secretaria Estadual do Esporte e Lazer (SEL) para a participação do estado nas Paralimpíadas Escolares 2011.

A Divisão de Esporte Educacional da FUNDERGS, ao mesmo tempo que planejava as ações direcionadas ao esporte paralímpico escolar, que seriam implementadas no estado no ano seguinte, atuou em articulações nas esferas governamentais, buscando apoio financeiro para a viagem de delegação do RS ao evento nacional, conforme as metas traçadas em documento elaborado pela Fundação de Articulação e Desenvolvimento de Políticas Públicas para Pessoas com Deficiência e com Altas Habilidades no Rio Grande do Sul (FADERS), da Secretaria de Justiça e Direitos Humanos (SJDH), e pela FUNDERGS. Iniciou-se, assim, a segunda fase, da 
conformação, marcada pelo início dos incentivos governamentais, por meio de ações articuladas que ampliaram as oportunidades esportivas aos estudantes com deficiência, especialmente nas escolas. Essa fase caracteriza-se, também, pelo aumento no número de estudantes que passaram a compor as delegações, além de expressar melhorias no desempenho durante a competição.

Desta maneira, na edição das Paralimpíadas Escolares de 2011, além do atletismo paralímpico, o Rio Grande do Sul teve representantes nas modalidades de judô, natação e tênis de mesa, totalizando 44 integrantes na delegação, sendo 20 estudantes e 24 membros da equipe técnica, os quais conquistaram a $16^{\mathrm{a}}$ colocação na classificação geral do evento. Vale a ressalva de que, nesse momento, o estado ainda não contava com competição seletiva estadual, conforme regra do evento nacional, tendo a sua delegação composta a partir do "encontro" de interessados a participar, incluindo estudantes e professores/técnicos. Na Figura 1 estão os representantes do Rio Grande do Sul nas Paralimpíadas Escolares 2011. Além dos estudantes com deficiência, constam na imagem professores de educação física e agentes de órgãos do governo do Rio Grande do Sul, como Pedro Paulo da Silva Guimarães (FUNDERGS) e Cláudia Alfama (FADERS).

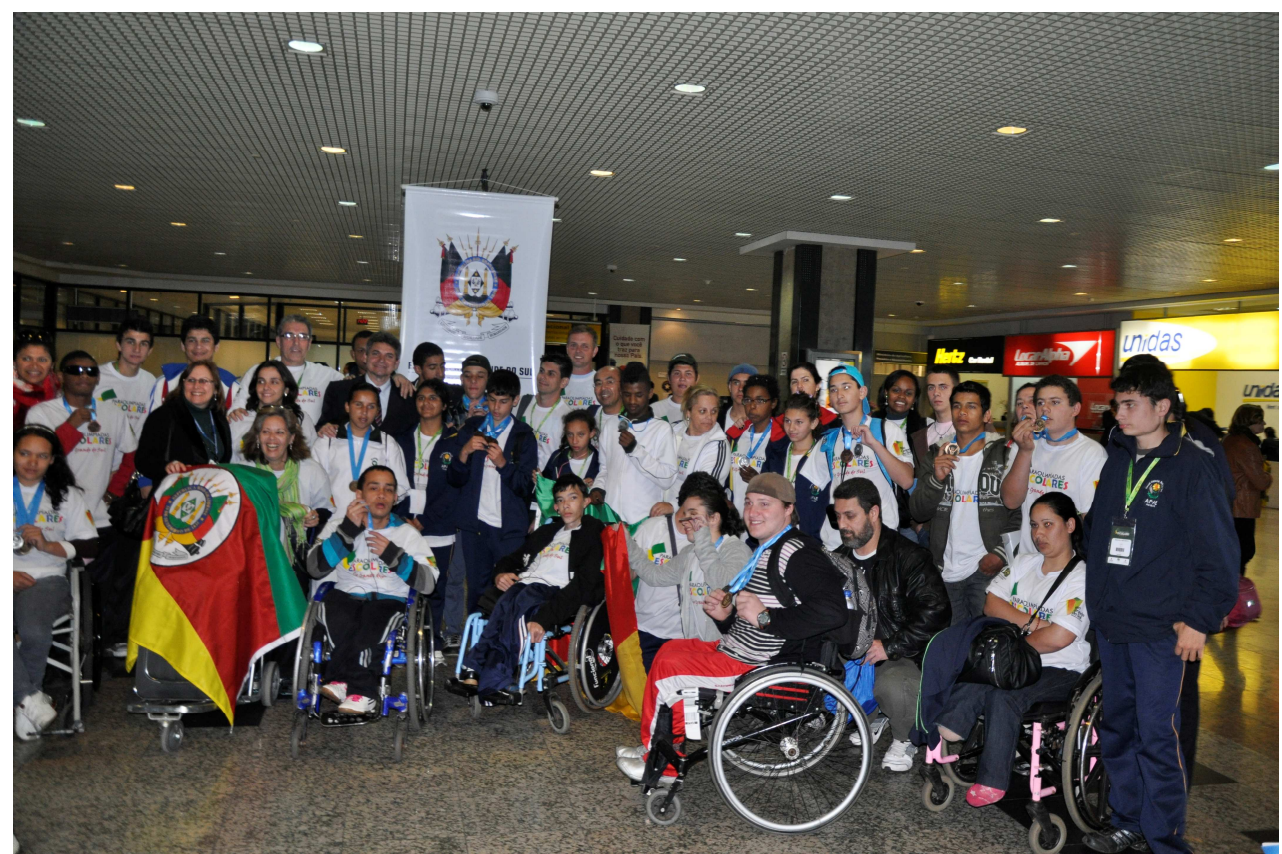

Figura 1 - Delegação do Rio Grande do Sul nas Paralimpíadas Escolares 2011 - imagem ilustrativa.

Fonte: Acervo do Observatório do Esporte Paralímpico - NEHME/PARALÍMPICO.

No ano seguinte, com as ações Clínica de Esportes Paralímpicos, Festival Paralímpico e PARACERGS já implantadas no estado, a delegação do Rio Grande do Sul nas Paralimpíadas Escolares foi composta por 73 pessoas - 39 estudantes e 34 integrantes da equipe técnica. Além das modalidades já disputadas na edição anterior, em 2012, o estado contou com representantes nas disputas de bocha paralímpica. Os resultados do Rio Grande do Sul nessa edição do evento 
trouxe representações, as quais podem ser evidenciadas em notícia veiculada pelo jornal Folha de São Borja, meio de comunicação em formato impresso do município de São Borja/RS. As representações podem ser evidenciadas nos dizeres da reportagem que anunciava a conquista de medalha de bronze na corrida com cadeira de rodas, na distância de 300 metros, e a medalha de ouro na disputa de arremesso de pelota: "O estudante Willian Silva Guasso, 13 anos, foi recebido com muita festa em São Borja. Ele teve direito a carreata pela cidade na segunda-feira, dia 22, e a recepção calorosa na Escola Estadual João Goulart, bairro Pirahy, onde estuda" (ATLETA DE SÃO BORJA..., 24 out. 2012). Na notícia é possível evidenciar que a representação do estudante nas Paralimpíadas Escolares se deu por intermédio do vínculo escolar. O acompanhamento do professor de educação física Anderson Jungton a Willian no evento nacional (Figura 2) traz indícios de que a preparação do estudante para as disputas nas provas do atletismo sucedeu em contexto escolar, em consonância com os pressupostos das ações implementadas pela FUNDERGS/SEL no estado naquele mesmo ano. Em continuação, registrou-se que o estudante conquistou vaga para as Paralimpíadas Escolares a partir da conquista dos primeiros lugares ao disputar, no PARACERGS, as modalidades supramencionadas.

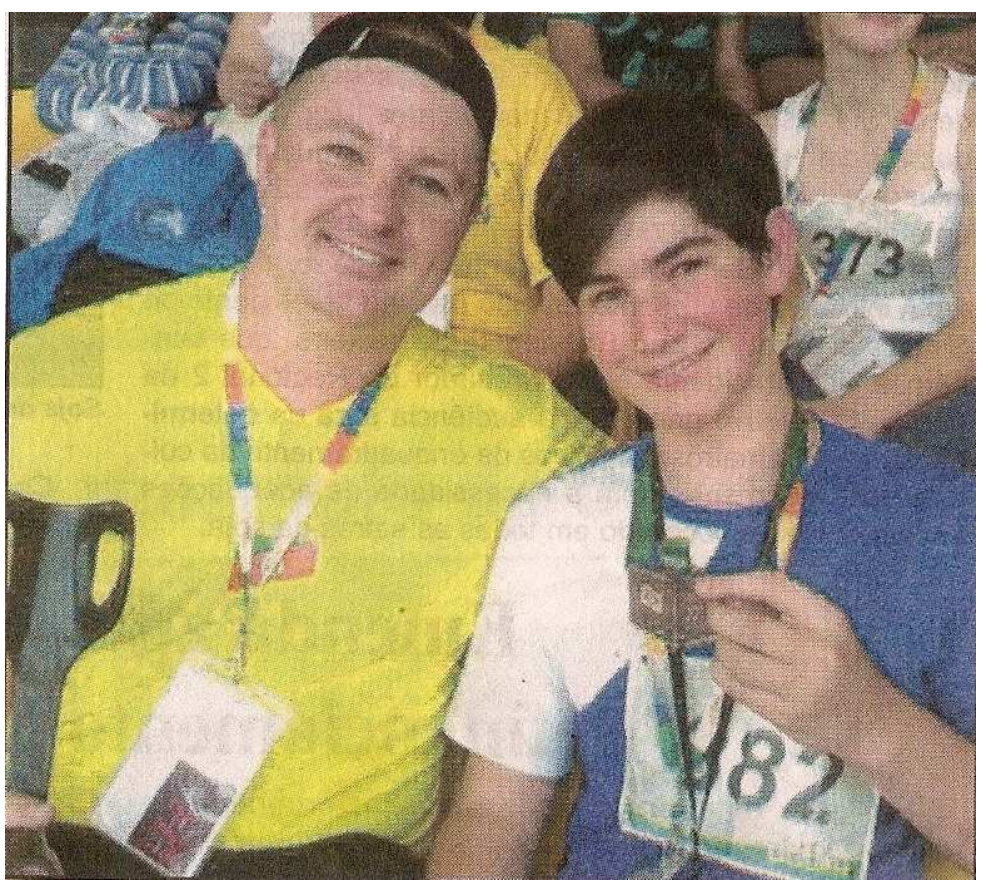

Figura 2 - O professor de educação física Anderson Jungton e o estudante Willian Silva Guasso, de São Borja/RS, nas Paralimpíadas Escolares 2012 - imagem ilustrativa.

Fonte: Imagem da notícia veiculada pelo jornal Folha de São Borja em 24 de outubro de 2012. Acervo do Observatório do Esporte Paralímpico - NEHME/PARALÍMPICO.

Ainda a referida reportagem faz uso de palavras do vereador da Câmara Municipal de São Borja, Beto Silva, o qual protocolou moção com votos de congratulações ao estudante Willian em função de seu feito esportivo, destacando: "é justa porque a vitória dele foi a vitória 
da superação, e sua conquista serve de exemplo para todos nós". A fala do vereador parece carregar representações comumente evidenciadas no campo do esporte paralímpico, em que as conquistas dos atletas são pautadas pelos ideais de superação da condição patológica da deficiência e de feitos heróicos, em detrimento do desempenho esportivo na modalidade disputada. Nesta direção, o estudo de Lins et al (2019) menciona a importância de se valorizar as experiências e os sentimentos de cada atleta com deficiência, mas também enfatizam a necessidade de se reconhecer que esses atletas não são casos individuais de superação e sucesso. Em vez disso, eles fazem parte de um movimento social mais amplo, no caso, o movimento paralímpico, em que o grupo de pertencimento conquista e reconstrói um lugar dentro dessa representação. Romper com os estereótipos "individualizantes e patologizantes" que ainda permeiam o universo do esporte paralímpico, evidenciados frequentemente em veículos de comunicação, poderia colaborar para se avançar nos pressupostos da inclusão social das pessoas com deficiência por meio do esporte, seja em nível escolar ou no alto rendimento.

No ano de 2013, o número de representantes do Rio Grande do Sul nas Paralimpíadas Escolares teve novo aumento, contando com 49 estudantes e 38 membros da equipe técnica. Nesta edição, pela primeira vez o estado conseguiu compor equipe para competir em uma modalidade coletiva, qual seja: goalball, sendo esta a única que contou com equipe representante do estado até o ano de 2017, quando o estado conseguiu compor equipe de futebol de sete (BOLETIM..., 2013; BOLETIM..., 2017). Há indícios de que Cláudia Romero, professora de educação física do município de Novo Hamburgo/RS, atuou na composição de equipes de goalball para representar o estado nas Paralimpíadas Escolares (ALFAMA, 26 nov. 2018). Vale referir que reunir o número suficiente de estudantes com deficiência para "treinar" as devidas modalidades, conforme os critérios de elegibilidade de cada uma, não é uma tarefa fácil para os estados. Isto porque os estudantes com as características necessárias para cada modalidade, muitas vezes, residem em municípios distintos, dificultando o encontro para a realização de "treinos".

A delegação sul-rio-grandense, de 87 integrantes, conquistou a $13^{\text {a }}$ colocação na classificação final do evento nacional em 2013. Representações que emergiram do incremento do desempenho do estado nas Paralimpíadas Escolares, talvez, motivaram a criação, no mesmo ano, do projeto "Esporte+ Paradesporto Escolar" com a finalidade de preparar estudantes com deficiência para competições esportivas paralímpicas, incluindo, especialmente, o PARACERGS e as Paralimpíadas Escolares (MALANOVICZ; MARTINS; MALANOVICZ, 2017a). Tal projeto é vinculado à Associação Esporte +, também fundada em 2013, em Porto Alegre/RS, pelas professoras de educação física Ana Paula Vieira Malanovicz, Aline Vieira Malanovicz e Fernanda Michaelsen Martins, com objetivos direcionados à inclusão social de estudantes com e sem deficiência, oriundos de comunidades carentes, por meio da prática 
esportiva das modalidades do atletismo e da natação (MALANOVICZ; MARTINS; MALANOVICZ, 2017b). Tais ações são de cunho não governamental.

Apesar das conquistas e representações construídas no Rio Grande do Sul ao longo das três participações consecutivas nas Paralimpíadas Escolares, no ano de 2014, em congruência com a ruptura evidenciada no evento nacional, o número de integrantes da delegação sul-riograndense caiu para 39, ou seja, menos da metade dos participantes da edição do ano anterior. Em contexto regional, uma possível explicação para isso pode estar relacionada à mudança de gestão política que se processava no Rio Grande do Sul. Isto, possivelmente, impactou na organização da sua delegação, que era realizada por órgão do governo desde o ano de 2011. Tal descontinuidade não causou prejuízos em termos do desempenho da delegação participante do evento, a qual conquistou a $10^{\mathrm{a}}$ colocação na classificação geral final, sendo esta a melhor posição do estado desde a primeira participação.

Com a efetivação de nova gestão política no estado em $1^{\circ}$ de janeiro de 2015 , novo órgão é discriminado para atuar no campo do esporte, da cultura, do turismo e do lazer, denominado Secretaria de Estado da Cultura, Turismo, Esporte e Lazer (SEDACTEL). Esta secretaria, deste modo, configurou o novo órgão responsável pelo desenvolvimento das ações no âmbito do esporte paralímpico escolar, contemplando tanto as atividades de capacitação profissional quanto de promoção da participação dos estudantes com deficiência na prática e na competição de modalidades paralímpicas. A organização e a viabilização da participação de delegação sul-rio-grandense fica, a partir de então, sob responsabilidade da SEDACTEL.

Dadas as referidas mudanças de governo, a partir do ano de 2015, a quantidade de representantes do Rio Grande do Sul nas Paralimpíadas Escolares volta a crescer, apresentando 57 participantes nesse ano e 59 em ambos os subsequentes. Porém, em 2016, o Rio Grande do Sul não contou com representantes na modalidade do goalball, assim como em 2017, no tênis de mesa, refletindo dificuldades em sua composição, ainda que tais modalidades tivessem sido representadas por estudantes do estado nos anos anteriores. Nesse cenário, vale referir que, ao completar 18 anos de idade ou ao encerrar o vínculo escolar, os jovens com deficiência não atendem mais aos critérios para inscrição nas Paralimpíadas Escolares. Com isso, muitas vezes, o estado deixa de contar com representantes que competiram nas distintas modalidades em edições do evento. Por outro lado, apresentando desempenho de destaque, tais indivíduos podem se engajar em outras competições e oportunidades no campo do esporte paralímpico.

Entre as edições das Paralimpíadas Escolares de 2014 e 2017, as delegações do estado do Rio Grande do Sul assumiram a $9^{\mathrm{a}}$ e a $10^{\mathrm{a}}$ colocações na classificação geral final do evento. Para além das representações oriundas das escolas, a partir do ano de 2014 começam a emergir indícios de modificações no cenário do esporte paralímpico escolar no estado com a inserção de entidades esportivas nesse campo. Um exemplo advém dos estudantes com deficiência que recebem suporte para treinamento no Projeto Esporte+ Paradesporto Escolar, da Associação 
Esporte+. Segundo as diretoras da entidade, os integrantes do projeto obtiveram destaque em competições esportivas paralímpicas regionais, como o PARACERGS, conquistando índices para a competição nacional:

[...] Os resultados são as convocações de atletas e técnicos para compor a delegação gaúcha nas Paralimpíadas Escolares nos anos de 2014, 2015 e 2016, convocação de atleta para Seleção Brasileira de Jovens, convocação de atleta para o Open Internacional Loterias Caixa e reconhecimento de técnicas e atletas como destaques em âmbito estadual (MALANOVICZ; MARTINS; MALANOVICZ, 2017b, p. $55)$.

Desta feita, nota-se a construção de representações que se aproximam do esporte paralímpico de alto rendimento, uma vez que a ênfase é colocada nas conquistas e no reconhecimento social resultante disso às "técnicas" e aos "atletas" no contexto do estado. As autoras supracitadas, também técnicas da referida associação, ressaltaram em seu estudo que, apesar de o Projeto Esporte+ Paradesporto Escolar dispor de poucos recursos financeiros, em três anos de desenvolvimento oportunizou benefícios aos seus participantes, tendo em vista as suas conquistas nas competições disputadas, com destaque para as Paralimpíadas Escolares.

Em termos das representações circunscritas no universo das escolas, nota-se que a mudança governamental sucedida em 2015 acarretou o enfraquecimento das ações implementadas na gestão anterior, particularmente no que diz respeito à Clínica de Esportes Paralímpicos e ao Festival Paralímpico, devido à ruptura das articulações entre estado e municípios para o desenvolvimento das ações. Desta maneira, as iniciativas nesse âmbito passaram a depender de vontade política local. Conforme Vidal (2014), é fundamental que as ações esportivas, em nível estadual, sejam construídas em estreita relação com órgãos municipais, pois cada localidade possui necessidades específicas. Respeitar tais singularidades deve constituir responsabilidade primeira de qualquer ação no âmbito esportivo. Ademais, é preciso que as ações implementadas em nível estadual, sejam adotadas pela esfera municipal, compreendendo-a como responsabilidade mútua, pois são os agentes regionais que, antes e após a participação nas ações estaduais, têm a possibilidade de desenvolver trabalhos que atendam às necessidades e potencialidades presentes em seus contextos de atuação, contemplando objetivos de longo prazo.

Nesta perspectiva, encontramos vestígios de capacitação de professores de educação física promovida em âmbito local, no município de Novo Hamburgo/RS, durante o período de fevereiro a dezembro de 2016, visando a instrumentalizar a atuação docente junto aos estudantes com deficiência nas escolas, bem como o desenvolvimento de festivais e oficinas com o intuito de que a prática esportiva paralímpica pudesse ganhar forças nos ambientes de ensino regular e, também, ultrapassá-los ao serem adotadas como práticas cotidianas dos estudantes (ROMERO, 2017). Segundo a autora, além de estimular e inclusão social, essa 
iniciativa resultou na ampliação do número de inscritos do referido município no PARACERGS, contribuindo para o incremento da seletiva estadual do Rio Grande do Sul às Paralimpíadas Escolares. Ao identificar que a maior parcela dos estudantes participantes do evento nacional possui vínculo com instituições de ensino públicas, o estudo de Reis, Silva e Mezzadri (2017) reforça a importância da capacitação de professores de educação física, de modo que estes estejam preparados para trabalhar as modalidades paralímpicas no interior desses contextos. Todavia, não descartamos a igual relevância dos trabalhos realizados em associações e projetos sociais, entre outros.

Quadro 1 - Informações sobre as delegações do estado do Rio Grande do Sul nas Paralimpíadas Escolares.

\begin{tabular}{|c|c|c|c|c|c|}
\hline Ano & Modalidades & Estudantes & $\begin{array}{l}\text { Equipe } \\
\text { técnica }\end{array}$ & Delegação & $\begin{array}{c}\text { Classificação } \\
\text { Geral Final }\end{array}$ \\
\hline 2010 & Atletismo & 4 & 6 & 10 & $22^{\circ}$ \\
\hline 2011 & $\begin{array}{c}\text { Atletismo } \\
\text { Judô } \\
\text { Natação } \\
\text { Tênis de Mesa }\end{array}$ & 20 & 24 & 44 & $16^{\circ}$ \\
\hline 2012 & $\begin{array}{c}\text { Atletismo } \\
\text { Judô } \\
\text { Natação } \\
\text { Tênis de mesa } \\
\text { Bocha }\end{array}$ & 39 & 34 & 73 & $18^{\circ}$ \\
\hline 2013 & $\begin{array}{c}\text { Atletismo } \\
\text { Judô } \\
\text { Natação } \\
\text { Tênis de mesa } \\
\text { Bocha } \\
\text { Goalball } \\
\end{array}$ & 49 & 38 & 87 & $13^{\circ}$ \\
\hline 2014 & $\begin{array}{c}\text { Atletismo } \\
\text { Judô } \\
\text { Natação } \\
\text { Tênis de mesa } \\
\text { Bocha } \\
\text { Goalball } \\
\end{array}$ & 21 & 18 & 39 & $10^{\circ}$ \\
\hline 2015 & $\begin{array}{c}\text { Atletismo } \\
\text { Judô } \\
\text { Natação } \\
\text { Tênis de mesa } \\
\text { Bocha } \\
\text { Goalball } \\
\end{array}$ & 31 & 26 & 57 & $9^{\circ}$ \\
\hline 2016 & $\begin{array}{c}\text { Atletismo } \\
\text { Judô } \\
\text { Natação } \\
\text { Tênis de mesa } \\
\text { Bocha }\end{array}$ & 34 & 25 & 59 & $10^{\circ}$ \\
\hline 2017 & $\begin{array}{l}\text { Atletismo } \\
\text { Judô } \\
\text { Natação } \\
\text { Bocha }\end{array}$ & $*$ & $*$ & 59 & $9^{\circ}$ \\
\hline
\end{tabular}




\begin{tabular}{|c|c|c|c|c|c|}
\hline & $\begin{array}{c}\text { Goalball } \\
\text { Futebol de sete }\end{array}$ & & & & \\
\hline 2018 & $\begin{array}{c}\text { Atletismo } \\
\text { Judô } \\
\text { Natação } \\
\text { Tênis de mesa } \\
\text { Bocha } \\
\text { Futebol de } \\
\text { cinco } \\
\text { Futebol de sete }\end{array}$ & 55 & $*$ & $*$ & $6^{\circ}$ \\
\hline
\end{tabular}

Fonte: Informações obtidas nos boletins das edições de 2010 a 2018 das Paralimpíadas Escolares.

Legenda: *= Informação não localizada nas fontes analisadas.

Os vestígios obtidos a partir da análise das informações coletadas apontam que, após ser inserido nas políticas públicas de esporte e lazer do estado, o esporte paralímpico escolar passou a contar com práticas que, no ano de 2018, posicionaram o estado entre os seis primeiros colocados na classificação geral das Paralimpíadas Escolares (PARALIMPÍADAS..., 2018). Notamos, de tal modo, o início da terceira fase - a fase de incremento -, na qual o estado apresentou modificações em suas representações nas Paralimpíadas Escolares. Após finalizar quatro edições consecutivas da competição com a $9^{\mathrm{a}}$ e a $10^{\mathrm{a}}$ colocação final, o estado deu um salto quantitativamente relevante em termos de desempenho da delegação nas modalidades. Além da representatividade em termos quantitativos, as composições do objeto no Rio Grande do Sul suscitaram iniciativas (governamentais, não governamentais e privadas), promovendo a inclusão de estudantes com deficiência em diversas modalidades paralímpicas que integram a competição nacional.

No período de oito anos, após a primeira participação do estado no evento, os estudantes com deficiência do Rio Grande do Sul passaram da invisibilidade nas Paralimpíadas Escolares para a condição de destaques na edição de 2018. A partir do desempenho nas Paralimpíadas Escolares 2018, apenas na modalidade da natação, seis estudantes sul-riograndenses vinculados à Associação Esporte+ foram selecionados para integrar o Camping Escolar Paralímpico ${ }^{8}$ 2019, além de representantes de outras modalidades disputadas. Ademais, dois estudantes foram convocados para participar da $1^{\text {a }}$ Fase de Treinamento - Seleção Sub-18 de Natação, na condição de atletas, no Centro de Treinamento Paralímpico Brasileiro, em São Paulo.

$\mathrm{Na}$ ocasião da finalização da competição, o governo do estado veiculou notícia em seu site: "Das 69 medalhas gaúchas nas Paralimpíadas Escolares 2018, 35 são de ouro, 20 prata e 14

\footnotetext{
${ }^{8}$ O Camping Escolar Paralímpico consiste na realização de duas semanas de treinamento intensivo com os estudantes que se destacam nas edições das Paralimpíadas Escolares. Nesse período, os estudantes selecionados são hospedados no setor residencial do Centro de Treinamento Paralímpico, em São Paulo, sendo acompanhados em termos de treinamento, avaliação, alimentação e segurança. Tal ação foi implantada pelo CPB no ano 2018, contando com duas fases de realização por ano (CAMPING ESCOLAR..., 30 jan. 2019).
} 
bronze. Destas, 35 foram obtidas no atletismo, 27 na natação, uma no judô, uma na bocha, três no tênis de mesa, uma no futebol de 7 e uma no futebol de 5" (PARALIMPÍADAS..., 26 nov. 2018). Na sequência da reportagem, é possível constatar que a delegação do estado obteve medalhas em todas as provas nas quais competiu. Todavia, salvo a coordenação da delegação por órgão do estado, não são apresentados os nomes dos agentes e instituições envolvidos nas conquistas, exceto o ressalto: “A judoca Lauren Lannes de Melo ganhou prêmio de destaque da categoria A (12 a 14 anos). O alto desempenho dos atletas gaúchos chamou atenção das seleções nacionais das modalidades". Desse modo, nossa compreensão é a de que a competição Paralimpíadas Escolares motivou o estabelecimento de práticas que suscitam as atuais representações do esporte paralímpico escolar no Rio Grande do Sul, ou seja, representações que se aproximam do esporte paralímpico de alto rendimento.

Outrossim, nas Paralimpíadas Escolares 2018, o Rio Grande do Sul apresentou o diferencial de disputa nas modalidades coletivas do futebol de cinco, pela primeira vez, e futebol de sete, com o destaque de integrantes da equipe. A composição das equipes foi viabilizada pelo trabalho desenvolvido por entidades e profissionais de educação física do estado: A Associação Gaúcha de Futsal para Cegos (AGAFUC), de Canoas/RS, em parceria com o professor de educação física Felipe de Oliveira Motta, de Rio Grande/RS, formaram a equipe de futebol de cinco com três estudantes com deficiência visual de cada município. A equipe sul-rio-grandense de futebol de cinco conquistou o troféu de bronze em sua primeira participação nas Paralimpíadas Escolares. Na ocasião, a AGAFUC postou mensagem em rede social, parabenizando os integrantes da equipe pela conquista. Além da representação em torno dos "atletas", foram destacados os nomes do técnico da AGAFUC, Rafael Astrada, e do professor Felipe de Oliveira Motta, os quais acompanharam a equipe no evento nacional (AGAFUC..., 23. nov. 2018).

Por sua vez, a equipe de futebol de sete foi organizada pela coordenadora da área de educação física da FADERS, Cláudia Alfama, que assumiu a posição de técnica da modalidade desde 2017 e acompanhou os integrantes nas Paralimpíadas Escolares. Em 2018 foram reunidos 10 estudantes com as deficiências elegíveis para a modalidade, oriundos de instituições de ensino de distintos municípios do estado: Porto Alegre, Novo Hamburgo, Caxias do Sul, Sapiranga, Campo Bom e Alvorada. O grupo realizou treinos da modalidade em Porto Alegre nos meses de setembro, outubro e novembro, quando sucedeu o evento nacional, edição 2018. $\mathrm{Na}$ ocasião, a equipe de futebol de sete (Figura 3) conquistou a primeira medalha em modalidade coletiva das Paralimpíadas Escolares para o estado do Rio Grande do Sul. Ao realizar gol no primeiro jogo da competição, contra a equipe do estado de São Paulo, a técnica sul-rio-grandense relembra a manifestação da equipe: "fizemos nosso primeiro gol... e comemoramos como final de mundial" (ALFAMA... 26. nov. 2018). Como em toda competição esportiva, as disputas no evento paralímpico escolar investigado causam sentimentos, 
manifestados em representações coletivas imediatamente no ato de acertos e erros. A Figura 3 ilustra o momento de registro da conquista de medalhas pela equipe. Além dos 10 estudantes que integraram a equipe, estão na imagem a técnica Cláudia Alfama e a auxiliar técnica Ana Andrioli.

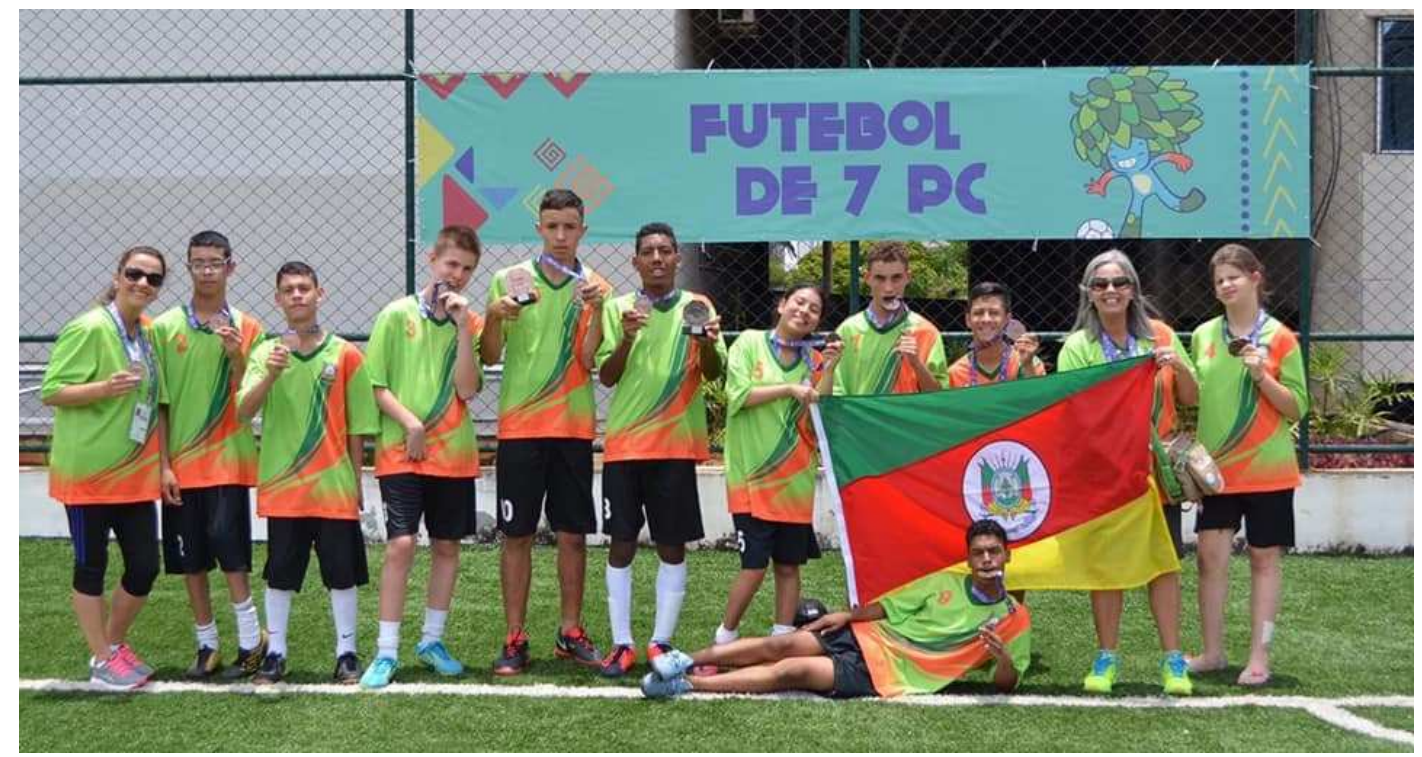

Figura 3 - Equipe da modalidade do futebol de sete, representante do Rio Grande do Sul nas Paralimpíadas Escolares 2018 - imagem ilustrativa.

Fonte: ALFAMA (26 nov. 2018).

Ao final das Paralimpíadas Escolares 2018, a equipe sul-rio-grandense de futebol de sete conquistou o troféu de prata na classificação final da modalidade. Além disso, o estudante Ricardo Laranjeira recebeu o troféu de artilheiro, após 10 gols feitos na competição. Com os resultados obtidos, ele e mais dois "atletas" da equipe foram selecionados para o Camping Escolar Paralímpico 2019. Sobre isso, Cláudia Alfama publicou em sua rede social: “[...] Sobre 27/11/2018... Sobre Paralimpíadas Escolares... Sobre Oportunidades... Sobre Sonhos... Muito orgulho de ter feito parte do sonho de VOCÊS.. Bora lá dia 29/01 em São Paulo e conquistem tudo o que é direito de VOCÊS!!! [...]” (ALFAMA..., 23 jan. 2019).

$\mathrm{Na}$ postagem supracitada é possível evidenciar a compreensão das Paralimpíadas Escolares como um evento que materializa "oportunidades" e "sonhos", em especial àqueles que apresentam o desempenho desejado pelos "olheiros" do CPB. Nessa conjuntura é que integrantes da delegação sul-rio-grandense foram selecionados para mais um evento promovido pela entidade nacional, que, nas ocasiões, busca talentos paralímpicos. A fala de Cláudia Alfama traz, ainda, representações das oportunidades no seio do movimento paralímpico brasileiro, enquanto um direito das crianças e jovens com deficiência, isto é, o sonho da carreira paralímpica pode depender do talento, mas também da efetivação do direito à inclusão social da 
pessoa com deficiência por meio do esporte, direito este garantido pela Lei Brasileira de Inclusão - Lei federal n 13.146, de 6 de julho de 2015 (BRASIL, 2015).

Vale referir que a equipe sul-rio-grandense a disputar a modalidade do futebol de sete nas Paralimpíadas Escolares 2018 contou com duas integrantes do sexo feminino, atendendo a obrigatoriedade presente no regulamento do evento. Ao divulgar foto das três estudantes mulheres em rede social, a professora de educação física Cláudia Romero, do município de Novo Hamburgo/RS, relatou orgulho das "gaúchas do futebol de sete": "Muito orgulho dessa foto: mulheres poderosas, guerreiras estreando o futebol de sete nas Paralimpíadas Escolares São Paulo 2018. E tem gaúcha nessa história, aliás, duas gaúchas. Parabéns meninas, vocês me representam!” (ROMERO, 30 nov. 2018). Segundo informação veiculada, o estado do Rio Grande do Sul foi o único que teve estudantes do sexo feminino participando em tempo integral de todas as partidas disputadas por sua equipe, demonstrando seu efetivo engajamento na competição e não o mero cumprimento da regra exposta.

Ao serem veiculadas publicações em mídias sociais sobre a participação da equipe de futebol de sete nas Paralimpíadas Escolares 2018, professoras de educação física de distintos municípios do estado, como Ana Andrioli, de Sapiranga/RS, Cláudia Romero, de Novo Hamburgo/RS, e Fernanda Michaelsen, de Porto Alegre/RS, registraram o seu agradecimento à Cláudia Alfama pelo empenho em formar e treinar a equipe. Fernanda Michaelsen ainda revelou o seu orgulho como professora: "Muito orgulhosa desses meus alunos e atletas Ricardo Laranjeira e Pedro Lucas, da Escola Estadual Sarmento Leite. Obrigada, meus anjos, por me darem tanta felicidade!" (MICHAELSEN, 27 nov. 2018). A professora também agradeceu ao $\mathrm{CPB}$, pelas vagas concedidas aos estudantes sul-rio-grandenses para o Camping Escolar Paralímpico, e a Cláudia Alfama por ter "treinado os estudantes com êxito".

Por sua vez, Cláudia Alfama publicou mensagem relembrando os primórdios das composições históricas das Paralimpíadas Escolares no Rio Grande do Sul, indicando que as conquistas alcançadas em 2018 somente foram possíveis porque práticas e representações foram negociadas e renegociadas ao longo de um processo de oito anos:

“[...] Essa conquista só foi possível porque em 2010 duas profissionais de educação física de Passo Fundo, Margarete Trombini e Doris Flores e Souza iniciaram a participação do RS nas Paralimpíadas Escolares com quatro atletas na modalidade de atletismo. Em 2011 a Faders Acessibilidade Inclusão cumpriu com seu papel de articuladora da Política Pública para Pessoas com Deficiência e Altas Habilidades e levou a Secretaria Estadual de Esporte e Fundergs a importância de uma efetiva política pública na área do esporte para pessoas com deficiência, iniciando, assim, parceria entre Faders, Fundergs, Associações Esportivas e entidades para efetivação da política pública e construção do Festival Paralímpico, Parajirg's, Paracerg's, Jasrs e participação de alunos com deficiência intelectual, física e visual nas 
Paralimpíadas Escolares - Etapa Nacional [...]" (ALFAMA, 26 nov. 2018).

Além do reconhecimento das profissionais que incitaram a organização do estado para a sua vinculação nas Paralimpíadas Escolares, o trecho do discurso supracitado busca registrar a atuação dos referidos órgãos governamentais, reafirmando a FADERS enquanto articuladora e, talvez, desencadeadora, das políticas públicas desenvolvidas no campo do esporte paralímpico escolar, demarcando, particularmente, o período de gestão política que teve início no ano de 2011. Contudo, não deixou de registrar agradecimento a Fernanda Makvitz Rieger, do departamento de esporte das SEDACTEL, órgão substituto à SEL a partir de 2015, pelo intenso apoio concedido à delegação sul-rio-grandense no ano de 2018. Além disso, expôs o fundamental apoio de empresa privada do estado para a confecção dos uniformes esportivos para a equipe de futebol de sete e da Futpark Humaitá por ceder espaço físico para os seus treinos, trazendo indícios da ausência de apoio governamental para essas finalidades.

Logo, consideramos que as Paralimpíadas Escolares no Rio Grande do Sul fazem parte de um processo histórico que é atravessado por tensionamentos entre as entidades (secretarias, fundações, escolas, associações, clubes, entre outras) e os agentes envolvidos (dirigentes/coordenadores de órgãos públicos, professores, técnicos, estudantes com deficiência, familiares e outros), por vezes manifestos em meios de comunicação. De tal rede de relações emergem representações acerca do esporte paralímpico escolar. As representações são figuradas nos resultados de uma construção social que se dá a partir de indivíduos dotados de características ou interesses comuns, atuando em uma relação circunscrita na interseção da harmonia e do conflito, onde o poder, flutuante entre grupos, é constantemente anunciado. Os significados disso muitas vezes são evidenciados nas representações que discorrem ou silenciam sobre determinados órgãos, entidades e agentes no processo histórico das composições das Paralimpíadas Escolares no Rio Grande do Sul.

A análise das fontes relativas às ações implementadas pela FUNDERGS/SEL na gestão governamental de 2011 a 2015 trazem vestígios das intenções de que houvesse aproximação entre distintos agentes e instituições para a composição do campo do esporte paralímpico escolar no estado do Rio Grande do Sul, onde as Paralimpíadas Escolares figuram com papel preponderante. Tais evidências se fazem presentes no estabelecimento e no convite para parcerias com escolas, universidades, associações, clubes, incluindo seus agentes, em especial os professores de educação física e técnicos de modalidades paralímpicas.

As informações obtidas a partir da análise e do confronto das fontes revelam que essas relações não apenas foram materializadas, como modificaram o cenário e as representações do esporte paralímpico escolar no estado. Isto se dá, principalmente, nas e pelas Paralimpíadas Escolares, onde representações emergentes do desempenho dos atletas significam e ressignificam as práticas no contexto regional. De tal modo, nota-se que nosso objeto de estudo 
teve os primeiros arranjos de suas composições históricas amparados, especialmente, no ambiente escolar, o qual foi o foco inicial das ações governamentais que apostaram na capacitação profissional e na promoção do esporte paralímpico nesses espaços.

A disseminação inicial do objeto no estado foi sustentada, sobremaneira, em decorrência da articulação entre as ações de capacitação (clínicas de esportes paralímpicos), participação (festival paralímpico) e competição (PARACERGS), que visavam às Paralimpíadas Escolares. A concretização gradativa do melhor desempenho do estado na competição logo causou transformações nas composições do campo com a aderência de entidades esportivas na constituição das suas tramas. Vestígios obtidos nos permitem supor que a fundação da Associação Esporte+, no ano de 2013, contou com intensas motivações das representações construídas nas/pelas Paralimpíadas Escolares acerca dos potenciais de alto rendimento esportivo dos estudantes com deficiência do estado. Relevante relatar que tal fundação sucedeu pela iniciativa de professoras de educação física de escolas de municípios do estado, revelando, talvez, dificuldades para se desenvolver os objetivos do esporte paralímpico apenas por meio do contexto escolar.

Além da referida associação, entidades atuantes no campo do esporte paralímpico em período anterior à vinculação do estado às Paralimpíadas Escolares passaram a desenvolver projetos direcionados às crianças e jovens com deficiência - como exemplos, podemos citar a Associação RS Paradesporto e a AGAFUC. Afora a participação destas entidades, clubes esportivos passaram a colaborar por meio da cessão de espaços físicos para treinamentos. É o caso do Grêmio Náutico União de Porto Alegre/RS, com o qual a Associação Esporte+ possui parceria para a realização dos treinos de natação em piscina do clube. Embora essas novas instituições e seus agentes tenham adentrado as composições do objeto estudado no Rio Grande do Sul, aquelas que figuraram nos primórdios dessa construção permanecem atuando, de modo que, atualmente, podemos evidenciar uma rede de inter-relações nas/pelas Paralimpíadas Escolares no estado. Agentes e instituições que estiveram presentes desde as primeiras participações do estado na competição, como Cláudia Alfama (FADERS) e Felipe de Oliveira Motta (Prefeitura de Rio Grande/RS), continuam agindo no campo, apresentando estreita relação com as entidades e os agentes que ingressaram mais recentemente. Nesse cenário, as práticas e representações são constantemente (re)negociadas, convergindo, nos últimos anos, para caminhos que conectam o esporte paralímpico escolar e o alto rendimento esportivo. Indícios concretos disto foram conformados nas Paralimpíadas Escolares 2018.

\section{Conclusão}

Nossos resultados buscaram discorrer sobre o esporte paralímpico escolar no Rio Grande do Sul, enfocando, especificamente, como ocorreu a construção de ações que 
convergiram para fomentar a representação do estado nas Paralimpíadas Escolares. A análise das informações coletadas para este estudo corroborou com o fato de que as representações advindas da participação das delegações sul-rio-grandenses nas Paralimpíadas Escolares consistiram em um componente catalizador para o desenvolvimento do campo do esporte paralímpico escolar no estado. Assim, com a implementação de ações governamentais, os estudantes com deficiência passaram a contar com maior visibilidade e oportunidades de acesso ao esporte em escolas do estado. Por sua vez, a aderência de associações e clubes na oferta do esporte paralímpico ampliou as possibilidades de prática/treinamento dos estudantes em modalidades específicas, talvez mirando no alto rendimento esportivo e nas perspectivas de carreira paralímpica. Considera-se que o Rio Grande do Sul utilizou positivamente as representações procedentes das Paralimpíadas Escolares, conformando alterações no cenário do esporte para os estudantes com deficiência em distintos espaços.

Embora nem todos os estados do país, até o presente momento, desenvolvam iniciativas esportivas de longo prazo para estudantes com deficiência, acredita-se que as Paralimpíadas Escolares representem um importante incentivo para que tal panorama seja modificado, uma vez que o evento dá visibilidade a esse grupo e estimula a criação de oportunidades para a prática de esportes em seu contexto social. Nessa direção, no Rio Grande do Sul, as Paralimpíadas Escolares representam um evento catalisador para a construção e modificação de práticas aos estudantes com deficiência.

\section{Referências}

A FEDERAÇÃO - Quem somos. In: Portal da Federação das APAES do Estado do Rio Grande do Sul (FEAPAES-RS). Porto Alegre. Disponível em: http://www.apaers.org.br/federacao.asp?id=1. Acesso em: 19 mar. 2019.

AGAFUC CANOAS. Hoje encerrou as Paralimpíadas Escolares 2018. Canoas, 23. nov. 2018. Facebook: Agafuc Canoas. Disponível em: https://www.facebook.com/agafucfutebolde5. Acesso em: 20 fev. 2018.

ALFAMA, Cláudia. Se VOCÊS três pensam que eu esqueci de VOCÊS.... tenho algo à dizer.... BEM CAPAZ!!! Porto Alegre, 23 jan. 2019. Facebook: Cláudia Alfama. Disponível em: https://www.facebook.com/claudia.alfama.9/posts/2464934240215057. Acesso em: 20 fev. 2019.

ALFAMA, Cláudia. Sobre 23/11/18 (sexta-feira) às 10h:45. Porto Alegre, 26. nov. 2018. Facebook: Cláudia Alfama. Disponível em:

https://www.facebook.com/claudia.alfama.9/posts/2348274415214374. Acesso em: 20 fev. 2019.

ANDRADE, Andresa Caravage; ALMEIDA, Marco Bettine; ANDRADE, Douglas Roque; MONTEIRO, Carlos Bandeira. Análise documental das políticas públicas de incentivo às práticas físico-esportivas para pessoas com deficiência no Brasil: Perspectivas para as Paralimpíadas Rio-2016. Revista Gestão e Políticas Públicas, São Paulo, v. 4, n. 1, p. 106-127, jun. 2014. Disponível em: http://www.revistas.usp.br/rgpp/article/view/114318/112192. Acesso em: 1 mar. 2019. 
ANDRIOLI, Ana. Ainda sobre a participação nas Paralímpiadas Escolares, quero registrar meu agradecimento e reconhecimento à técnica da equipe de futebol de 7 PC Cláudia Alfama. Sapiranga, 30 nov. 2018. Facebook: Ana Andrioli. Disponível em: https://www.facebook.com/ana.andrioli.50/posts/2057297257650010. Acesso em: 20 fev. 2019.

ATLETA de São Borja ganhou duas medalhas na Paraolimpíada Escolar. São Borja: Folha de São Borja, 24 out. 2012. [Acervo pessoal do coordenador de Divisão de Esporte Educacional da FUNDERGS no período de 2011 a 2015].

BARROS, José D’ Assunção. Fontes Históricas: revisitando alguns aspectos primordiais para a Pesquisa Histórica. Mouseion: Revista do Museu e Arquivo Histórico La Salle, Canoas, n. 12, p. 129-159, mai./ago. 2012. Disponível em:

https://revistas.unilasalle.edu.br/index.php/Mouseion/article/viewFile/332/414. Acesso em: 1 mar. 2019.

BATAGLION, Giandra Anceski; GUIMARÃES, Pedro Paulo da Silva; MAZO, Janice Zarpellon. O paradesporto escolar no estado do Rio Grande do Sul e a sua vinculação nas Paralimpíadas Escolares (2010-2017). In: VI CONGRESSO PARADESPORTIVO INTERNACIONAL, 6., 2018, São Paulo. Anais [...]. São Paulo: Revista Brasileira de Medicina do Esporte, v. 24, n. 6, nov./dez., 2018. p. 98.

BATAGLION, Giandra Anceski; MAZO, Janice Zarpellon. Paralimpíadas Escolares (20062018): Evidências em mídias digitais acerca do evento esportivo. Recorde - Revista de História do Esporte, v. 12, n. 1, p. 1-42, 2019. Disponível em: https://revistas.ufrj.br/index.php/Recorde/article/view/25670/14055. Acesso em: 26 out. 2019.

BEGOSSI, Tuany Defaveri.; MAZO, Janice Zarpellon. O percurso esportivo das mulheres pioneiras no cenário paralímpico sul-rio-grandense. Revista Brasileira Ciência e Movimento, v. 24, n. 4, p. 143-155, 2016. Disponível em:

https://portalrevistas.ucb.br/index.php/RBCM/article/view/6815. Acesso em: 5 jun. 2018.

BOLETIM final das Paralimpíadas Escolares 2013. In: Site oficial do CPB, São Paulo, 2013. Disponível em: http://www.cpb.org.br/web/guest/paralimpiadas-escolares. Acesso em: 5 mai. 2018.

BOLETIM final das Paralimpíadas Escolares 2017. In: Site oficial do CPB, São Paulo, 2017. Disponível em: http://www.cpb.org.br/web/guest/paralimpiadas-escolares. Acesso em: 5 mai. 2018.

BRASIL. A educação física escolar especial, a inclusiva e as paraolimpíadas. n. 435. Brasília, DF: Câmara dos Deputados, Edições Câmara, 2011. 191 p. Série ação parlamentar. Disponível em: http://bd.camara.gov.br/bd/handle/bdcamara/5930. Acesso em: 1 mar. 2019.

BRASIL. Decreto n ${ }^{\circ}$ 6.949/2009. Convenção sobre os Direitos das

Pessoas com Deficiência. Disponível em:

http://www.pessoacomdeficiencia.gov.br/app/sites/default/files/publicacoes/convencaopessoasc omdeficiencia.pdf. Acesso em: 22 fev. 2019.

BRASIL. Lei no 13.146, de 6 de julho de 2015. Institui a Lei Brasileira de Inclusão da Pessoa com Deficiência (Estatuto da Pessoa com Deficiência). Disponível em:

http://www.planalto.gov.br/ccivil_03/_Ato2015-2018/2015/Lei/L13146.htm. Acesso em: 05 ago. 2018.

CAMPING Escolar Paralímpico começa nesta quarta com atividade em 11 modalidades. In: Site oficial do CPB, São Paulo, 30 jan. 2019. Disponível em: http://www.cpb.org.br/noticias//asset_publisher/lU3LNvrdeyoz/content/id/125468. Acesso em: 30 jan. 2019.

CARDOSO, Vinícius Denardin. Os desafios e as possibilidades do esporte paralímpico no estado de Roraima. In: SEMINÁRIO INTERNACIONAL PARALÍMPICO ESCOLAR, 1., 2017, São Paulo, Anais [...]. São Paulo: CPB/APB, 2017. p. 18.

CARDOSO, Vinícius Denardin. O desenvolvimento da carreira esportiva de atletas

paraolímpicos no Brasil. 2016. 2017 f. Tese (Doutorado). Universidade Federal do Rio Grande 
do Sul, Escola de Educação Física, Fisioterapia e Dança, Programa de Pós-graduação em Ciências do Movimento Humano, Porto Alegre, 2016. Disponível em: https://lume.ufrgs.br/handle/10183/149557. Acesso em: 5 mai. 2018.

FURTADO, Sabrina. As ações, os projetos e o financiamento do Comitê Paralímpico Brasileiro no período de 2010 a 2015. 2017. 126 f. Dissertação (Mestrado em Educação Física) - Setor de Ciências Biológicas, Universidade Federal do Paraná, Curitiba, 2017. Disponível em: https://acervodigital.ufpr.br/bitstream/handle/1884/47463/R\%20-\%20D\%20\%20SABRINA\%20FURTADO.pdf?sequence=1\&isAllowed=y. Acesso em: 1 mar. 2019.

GORLA, José Irineu; CALEGARI, Décio Roberto. O esporte como ferramenta de reconhecimento e valorização da pessoa com deficiência no Brasil. Conexões: Educação física, esporte e saúde, Campinas, v. 15, n. 2, p. 257-270, abr./jun. 2017. Disponível em: https://periodicos.sbu.unicamp.br/ojs/index.php/conexoes/article/view/8649230/16500. Acesso em: 1 mar. 2019.

GOULART, Leonardo Roberto. Trajetória das Paralimpíadas Escolares de 2009 a 2016. 48p. 2017. Monografia (Graduação). Departamento de Educação Física, Universidade Federal de Santa Catarina, Florianópolis, 2017. Disponível em: https://repositorio.ufsc.br/handle/123456789/177629. Acesso em: 13 dez. 2018.

GUIMARÃES, Pedro Paulo; et al. Clínicas Paralímpicas. In: TONDIN, Gilmar; VIDAL, José Rogério; FEIX, Eneida. Esporte e Lazer no Brasil: divisão de responsabilidades entre os entes federativos. 2014. Esporte e Lazer no Brasil: divisão de responsabilidades entre os entes federativos. 2014. Canoas, Porto Alegre: CORAG, 2014. p. 243-244.

HAIACHI, Marcelo de Castro; et al. O projeto paradesportivo de Sergipe e o legado social para as pessoas com deficiência. Brazilian Journal of Education, Technology and Society (BRAJETS) - Especial Section, "Disability, Education, Technology and Sport". v. 11, n. 1, p.160-175, jan-mar., 2018. Disponível em: http://cev.org.br/biblioteca/o-projeto-paradesportivode-sergipe-e-o-legado-social-para-as-pessoas-com-deficiencia/. Acesso em: 3 jan. 2019.

HIPÓLITO, Verônica Silva; WINCKLER, Ciro. Desenvolvimento dos atletas das Paralimpíadas Escolares - Estudo Piloto. In: CONGRESSO PARADESPORTIVO INTERNACIONAL, 6., 2018, São Paulo. Anais [...]. São Paulo: Revista Brasileira de Medicina do Esporte, v. 24, n. 6, nov./dez. 2019 p. 67.

LINS, Samuel; MELO, Cynthia, F; ALVES, Sara G; SILVA, Rúben L. "Our voices, our meaning": The social representations of sports for brazilian athletes with disabilities. Adapted Physical Activity Quarterly, United States of America, v. 36, n. 1, p. 1-19, jan. 2019. Disponível em: https://journals.humankinetics.com/doi/full/10.1123/apaq.2017-0206. Acesso em: 1 mar. 2019.

MACHADO, Mariana Campos Martins; et al. Paradesporto escolar no município de Blumenau/SC: inclusão e acessibilidade para todos. Extensio UFSC: Revista Eletrônica de Extensão. Florianópolis, SC, v. 14, n. 25, p. 103-123, 2017. Disponível em: https://periodicos.ufsc.br/index.php/extensio/article/view/1807-0221.2017v14n25p103. Acesso em: 9 jun. 2018.

MALANOVICZ, Ana Paula Vieira; MARTINS, Fernanda Michaelsen; MALANOVICZ, Aline Vieira. Associação Esporte+ inclusão social de pessoas com deficiência. In: SEMINÁRIO INTERNACIONAL PARALÍMPICO ESCOLAR, 1, 2017, São Paulo, Anais [...]. São Paulo: CPB/APB, 2017b. p. 54.

MALANOVICZ, Ana Paula Vieira; MARTINS, Fernanda Michaelsen; MALANOVICZ, Aline Vieira. Treinamento desportivo na Associação Esporte + de pessoas com deficiência em idade escolar para competições de alto rendimento. In: SEMINÁRIO INTERNACIONAL PARALÍMPICO ESCOLAR, 1, 2017, São Paulo, Anais [...]. São Paulo: CPB/APB, 2017a. p. 55.

MAZO, Janice Zarpellon; BEGOSSI, Tuany Defaveri; BERTOLDI, Rafaela; ASSMANN, Alice Beatriz. Jogos Paralímpicos Rio 2016: memórias esportivas de atletas sul-rio-grandenses. 
Brazilian Journal of Education, Technology and Society (BRAJETS) - Especial Section, "Disability, Education, Technology and Sport". v. 11, n. 1, jan-mar. 2018. Disponível em: http://www.brajets.com/index.php/brajets/article/download/455/246. Acesso em: 9 nov. 2018.

MICHAELSEN, Fernanda. CONVOCADOS!!! Porto Alegre, 27 nov. 2018. Facebook:

Fernanda Michaelsen. Disponível em:

https://www.facebook.com/fernanda.michaelsen.52/posts/2042552995767343. Acesso em: 20 fev. 2019.

NETO, Alvaro Rego Millen; ABRAHÃO, Bruno Otávio de Lacerda; MOURA, Diego Luz. Os megaeventos esportivos na agenda das políticas para a educação física escolar no estado do Rio de Janeiro. Pensar a Prática, Goiânia, v. 20, n. 4, out./dez. 2017. Disponível em: https://www.revistas.ufg.br/fef/article/view/41509/pdf. Acesso em: 1 mar. 2019.

OBSERVATÓRIO DO ESPORTE PARALÍMPICO. In: Site oficial do NEHME.Paralímpico. Disponível em: <https://www.ufrgs.br/nehmeparalimpico/>. Acesso em: 12 fev. 2019.

PANCOTTO, Heloísa Pereira. O esporte na agenda governamental das políticas públicas para pessoas com deficiência. Conexões: Educação Física, Esporte e Saúde, Campinas: SP, v. 15, n. 2, p. 142-171, abr./jun. 2017. Disponível em:

https://periodicos.sbu.unicamp.br/ojs/index.php/conexoes/article/view/8647453. Acesso em: 9 mar. 2018.

PARALÍMPIADAS Escolares 2018 encerra com alto desempenho gaúcho. In: Portal do Governo do Estado do Rio Grande do Sul. Porto Alegre, 26 nov. 2018. Disponível em: http://cultura.rs.gov.br/paralimpiadas-escolares-2018-encerramento. Acesso em: 18 fev. 2019.

PARALIMPÍADAS Escolares 2018. Regulamento Geral. In: Site oficial do CPB, São Paulo, 2018, p. 9. Disponível em: http://www.cpb.org.br/documents/20181/0/regulamento+novo++escolares+v4/5a9f36f7-8664-4291-93b4-9082583bbe00. Acesso em: 08 jan. 2019.

PARAOLIMPÍADAS escolares 2011 - Etapa Nacional. Relatório [da] SJDH e [da] SEL. Porto Alegre, 2011, 20 p. [Acervo pessoal do coordenador de Divisão de Esporte Educacional da FUNDERGS no período de 2011 a 2015].

REIS, Rafael Estevam; MEZZADRI, Fernando Marinho; SILVA, Marcelo Moraes e. As políticas públicas para o esporte paralímpico no Brasil: apontamentos gerais.

Corpoconsciência, Cuiabá: MT, v. 21, n. 1, p. 58-69, jan./abr. 2017. Disponível em: http://periodicoscientificos.ufmt.br/ojs/index.php/corpoconsciencia/article/view/4706. Acesso em: 07 jul. 2018.

REIS, Rafael Estevam; SILVA, Evelyn Andressa Gavioli da; MEZZADRI, Fernando Marinho. Esporte paralímpico escolar: Um mapemaneto das escolas responsáveis pelos atletas participantes das paralimpíadas escolares. In: SEMINÁRIO INTERNACIONAL PARALÍMPICO ESCOLAR, 1., 2017, São Paulo, Anais [...]. São Paulo: CPB/APB, 2017. p. 87.

RESENDE, Mariana Corrêa de. Análise do perfil psicológico de participantes brasileiros de paradesporto em nível escolar: Motivação e resiliência. 2018. 96 f. Dissertação (Mestrado em Psicologia) - Programa de Mestrado em Psicologia, Universidade Federal de São João Del Rei, São João Del Rei, 2018. Disponível em: https://ufsj.edu.br/portal2-

repositorio/File/ppgpsi/Publicacoes/Dissertacoes/Mariana\%20Correa\%20de\%20Resende.pdf. Acesso em: 1 mar. 2019.

ROMERO, Cláudia da Rosa. Paradesporto escolar: inclusão, oportunidades e possibilidades. In: SEMINÁRIO INTERNACIONAL PARALÍMPICO ESCOLAR, 1., 2017, São Paulo, Anais [...]. São Paulo: CPB/APB, 2017. p. 83.

ROMERO, Cláudia. Muito orgulho dessa foto, mulheres, poderosas, guerreiras estreando o futebol de sete nas Paralímpiadas Escolares São Paulo 2018. Novo Hamburgo, 30 nov. 2018. Facebook: Cláudia Romero. Disponível em: https://www.facebook.com/claudia.romero.50702/posts/2062124777201717. Acesso em: 20 fev. 2019. 
SCHERER, Roger Lima; GOULART, Leonardo Roberto; SERON, Bruna Barboza. Trajetória das Paralimpíadas Escolares de 2009 a 2017. In: Congresso Paradesportivo Internacional, 6. , 2018, São Paulo. Anais [...]. São Paulo: Revista Brasileira de Medicina do Esporte, v. 24, n. 6 , nov./dez., 2018, p. 128.

SEHBE, Kalil. Rio Grande do Sul: uma nova realidade para o esporte. In: TONDIN, Gilmar; VIDAL, José Rogério; FEIX, Eneida. Esporte e Lazer no Brasil: Divisão de responsabilidades entre os entes federativos. 2014. Esporte e Lazer no Brasil: divisão de responsabilidades entre os entes federativos. 2014. Canoas, Porto Alegre: CORAG, 2014. p. 150-155.

SENATORE, Vanilton. Paraolímpicos do futuro. In: CONDE, Antonio João Manescal; SOBRINHO, Pedro Américo de Souza; SENATORE, Vanilton. Manual de Orientação para os Professores de Educação Física: Introdução ao Movimento Paraolímpico. Brasília: Comitê Paraolímpico Brasileiro, 2006, 1CD-ROM.

SILVA, Evelyn Andressa Gavioli da. Projeto Paralimpíadas Escolares: Intenção, evolução, articulações e contribuições ao paradesporto educacional brasileiro. 2017. 138 f. Dissertação (Mestrado em Educação Física) - Setor de Ciências Biológicas, Universidade Federal do Paraná, Curitiba, 2017. Disponível em:

https://acervodigital.ufpr.br/bitstream/handle/1884/47150/R\%20-\%20D\%20-

\%20EVELYN\%20ANDRESSA\%20GAVIOLI\%20DA\%20SILVA.pdf?sequence=1\&isAllowed =y. Acesso em: 1 mar. 2019.

TONDIN, Gilmar; VIDAL, José Rogério; FEIX, Eneida. Esporte e lazer no Brasil: Divisão de responsabilidades entre os entes federativos. Porto Alegre: CORAG, 2014.

VIDAL, José Rogério. Fórum regional de gestão do esporte e lazer: uma estratégia na construção de sistemas municipais de esporte do RS. In: TONDIN, Gilmar; VIDAL, José

Rogério; FEIX, Eneida. Esporte e Lazer no Brasil: divisão de responsabilidades entre os entes federativos. 2014. Canoas, Porto Alegre: CORAG, 2014. p. 1193-1198.

Artigo recebido em: 26/06/2019

Artigo aceito para publicação em: 09/09/2019 